NBER WORKING PAPER SERIES

ECONOMICS VERSUS POLITICS: PITFALLS OF POLICY ADVICE

\author{
Daron Acemoglu \\ James A. Robinson \\ Working Paper 18921 \\ http://www.nber.org/papers/w18921
}

\author{
NATIONAL BUREAU OF ECONOMIC RESEARCH \\ 1050 Massachusetts Avenue \\ Cambridge, MA 02138 \\ March 2013
}

We thank David Autor, Chang-Tai Hsieh, Simon Johnson, John List, Suresh Naidu and Timothy Taylor for comments The views expressed herein are those of the authors and do not necessarily reflect the views of the National Bureau of Economic Research.

NBER working papers are circulated for discussion and comment purposes. They have not been peerreviewed or been subject to the review by the NBER Board of Directors that accompanies official NBER publications.

(C) 2013 by Daron Acemoglu and James A. Robinson. All rights reserved. Short sections of text, not to exceed two paragraphs, may be quoted without explicit permission provided that full credit, including (c) notice, is given to the source. 
Economics versus Politics: Pitfalls of Policy Advice

Daron Acemoglu and James A. Robinson

NBER Working Paper No. 18921

March 2013

JEL No. O20,P16,P48

\begin{abstract}
The standard approach to policy-making and advice in economics implicitly or explicitly ignores politics and political economy, and maintains that if possible, any market failure should be rapidly removed. This essay explains why this conclusion may be incorrect; because it ignores politics, this approach is oblivious to the impact of the removal of market failures on future political equilibria and economic efficiency, which can be deleterious. We first outline a simple framework for the study of the impact of current economic policies on future political equilibria- and indirectly on future economic outcomes. We then illustrate the mechanisms through which such impacts might operate using a series of examples. The main message is that sound economic policy should be based on a careful analysis of political economy and should factor in its influence on future political equilibria.
\end{abstract}

\author{
Daron Acemoglu \\ Department of Economics \\ MIT, E52-380B \\ 50 Memorial Drive \\ Cambridge, MA 02142-1347 \\ and CIFAR \\ and also NBER \\ daron@mit.edu \\ James A. Robinson \\ Harvard University \\ Department of Government \\ N309, 1737 Cambridge Street \\ Cambridge, MA 02138 \\ and NBER \\ jrobinson@gov.harvard.edu
}


The fundamental approach to policy prescription in economics derives from the recognition that the presence of market failures - like externalities, public goods, monopoly, and imperfect competition - creates room for well-designed public interventions to improve social welfare. This tradition, already clear in Pigou (1912), was elaborated by Samuelson (1947), and still provides the basis of most policy advice provided by economists. For example, the first development economists in the 1950s used market failure inspired ideas as the intellectual basis for the need for government intervention to promote development in poor countries (Killick 1978). Though belief in the ability of the government or the effectiveness of aid has waxed and waned, current approaches to development problems have much in common with this early tradition, even if they have become more sophisticated: in recognizing second-best issues, for instance, by incorporating informational frictions explicitly in policy design (for example, Townsend, 2011); in highlighting the specificity of the appropriate policy depending on context (for example, Rodrik, 2007); and in emphasizing the role of rigorous empirical methods in determining which sorts of interventions can be effective (for eample, Banerjee and Duflo, 2011). But in all of these approaches, politics is largely absent from the scene.

This neglect of politics is often justified - implicitly or explicitly —in one of three ways. The first is to maintain that politicians are basically interested, or induced to be interested, in promoting social welfare, for example, because socially efficient policy is what helps politicians to stay in power or get re-elected in models like Whitman $(1989,1995)$ and Mulligan and Tsui (2006, 2008).

The second is to view politics as a random factor, just creating potentially severe but unsystematic grit on the wheels of economic policymaking (for example, Sachs, 2005, or Banerjee's, 2012, argument that the Liberian dictator Samuel Doe's economic policies were disastrous because he did not understand "what was involved in being president").

The third justification recognizes that political economy matters, but maintains that "good economics is good politics," meaning that good economic policies necessarily relax political constraints (for example, Boycko, Shleifer and Vishny, 1995, and Banerjee and Duflo, 2011, in particular, p. 261, or Sachs et al., 2004). The implication is the same as the first two views: one could unwaveringly support good economic policies, assured that they will not only solve market failures but also unleash beneficial political forces - whatever those may be.

In this essay, we argue not only that economic advice will ignore politics at its peril 
but also that there are systematic forces that sometimes turn good economics into bad politics, with the latter unfortunately often trumping the economic good. Of course, we are not claiming that economic advice should shy away from identifying market failures and creative solutions to them, nor are we suggesting a blanket bias away from good economic policy. Rather, our argument is that economic analysis needs to identify, theoretically and empirically, conditions under which politics and economics run into conflict, and then evaluate policy proposals taking this conflict and the potential backlashes it creates into account.

Our basic argument is simple: the extant political equilibrium may not be independent of the market failure; indeed it may critically rest upon it. Faced with a trade union exercising monopoly power and raising the wages of its members, most economists would advocate removing or limiting the union's ability to exercise this monopoly power, and this is certainly the right policy in some circumstances. But unions do not just influence the way the labor market functions; they also have important implications for the political system. Historically, unions have played a key role in the creation of democracy in many parts of the world, particularly in Western Europe; they have founded, funded and supported political parties, such as the Labour Party in Britain or the Social Democratic parties of Scandinavia, which have had large impacts on public policy and on the extent of taxation and income redistribution, often balancing the political power of established business interests and political elites. Because the higher wages that unions generate for their members are one of the main reasons why people join unions, reducing their market power is likely to foster de-unionization. But this may, by further strengthening groups and interests that were already dominant in society, also change the political equilibrium in a direction involving greater efficiency losses. This case illustrates a more general conclusion, which is the heart of our argument: even when it is possible, removing a market failure need not improve the allocation of resources because of its impact on future political equilibria. To understand whether it is likely to do so, one must look at the political consequences of a policy - it is not sufficient to just focus on the economic costs and benefits.

To develop this argument more fully, we offer a simple theoretical framework clarifying the links between economic policy and the political equilibrium. We emphasize why, in the presence of political economy considerations, economic cost-benefit analysis is not sufficient, and also how, in contrast to standard second-best reasoning, our argument provides some pointers for what types of market failures, if removed, are most likely to 
have deleterious impacts on the political equilibrium. We highlight economic policies that strengthen the already dominant groups in society - conversely, weakening their political counterweights - as those that need to be studied more holistically, combining politics with economics, to avoid major unintended political consequences.

We then discuss three broad mechanisms generating circumstances under which good economic policy may make bad politics. First, economic rents in the present can affect political equilibria; policies that, in the process of solving market failures, reduce the economic rents for certain groups may have unintended political consequences, particularly when the rents that are destroyed are those of groups that are already weak, further tilting the balance of power in society. Second, even in the absence of changing rents, the distribution of income can effect the political equilibrium, which implies that the distributional effects of the policies that enhance economic efficiency cannot be ignored for an additional, political reason. Once again, policies that lead to a further increase in inequality would be the ones most likely to have counterproductive political implications. Third, political incentive compatibility constraints, which determine the interests a politician has to satisfy, may be violated for certain groups as a result of removing market failures, creating a political backlash. In each case, we provide a few examples to illustrate the mechanisms in action.

At this point, our mechanisms are mainly illustrative. Our purpose is to show that the issues highlighted by our framework are present in a number of important historical and current episodes, and that there are some important commonalities consistent with a basic political economy approach - in particular, linking the counterproductive political implications to economic policies that improve the standing of already dominant groups and interests in society. It goes without saying that a more systematic empirical and theoretical analysis of these issues is necessary to uncover the major regularities and lessons, enrich our views of how economics and politics interact, and delineate the circumstances, if any, where economists can go on abstracting from politics.

\section{A Simple Framework}

To assist in clarifying these ideas and to organize the discussion of mechanisms in the next section, consider a two-period model. Suppose an economic policy has to be chosen in both periods and there are no economic linkages between these two periods. In addition suppose that in the first period politicians have some freedom of choice over policy - in 
some sense there is a "window of policy opportunity" so that policy is not completely determined by vested interests or some political calculations. This policy choice might also be influenced by advice from economists, for example, aimed at correcting a market failure. In the second period, policies will be determined in a political equilibrium.

Let us first focus on the world of "economics without politics", where there is no political (as well as economic) linkage between the two periods. In such a world, the first-period policy choice can be made without any concern for the political equilibrium in the second period. ${ }^{1}$ However, the reality is that policy choices in the first period often strengthen some groups and weaken others, and thus will likely affect the political equilibrium in the second period. In turn, the political equilibrium will determine the choices made in the second period. Therefore, the objective of the welfare maximizing policy maker, and the advice given by economists, should not just be to solve market failures today, but should take into account the later political ramifications of this first

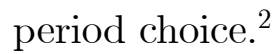

The argument so far is similar to a political version of the famous second-best caveat to economic policy analysis (Lancaster and Lipsey, 1956). But there is often more that can be said. Much political economy analysis highlights the role of the balance of political power in society, emphasizing in particular that (1) economic and political power are linked;

\footnotetext{
${ }^{1}$ Mathematically, in the world of "economics without politics," policies in the two periods, $x_{1}$ and $x_{2}$, are chosen independently to maximize welfare, $\sum_{t=1}^{2} W_{t}\left(x_{t}\right)$ (where discounting is suppressed without any loss of generality). Here $W_{t}$ captures social welfare in period $t$. In this case, the social welfare maximizing policy/advice in the first period would be $x_{1}^{S W}$ such that $W_{1}^{\prime}\left(x_{1}^{S W}\right)=0$.

${ }^{2}$ Mathematically, we can think of second-period policy being determined as $x_{2}=\xi\left(p_{2}\right)$, where $p_{2}$ is an index of the distribution of political power in the second period. This distribution of political power is itself determined in part by today's policies, which can be summarized by a function $\pi$, so that $p_{2}=\pi\left(x_{1}\right)$.

In contrast to the situation in footnote 1 , social welfare maximization in this world, where economic policies and politics in the future are endogenous, will require (assuming differentiability):

$$
W_{1}^{\prime}\left(x_{1}\right)+W_{2}^{\prime}\left(\xi\left(\pi\left(x_{1}\right)\right)\right) \frac{d \xi\left(\pi\left(x_{1}\right)\right)}{d p_{2}} \frac{d \pi\left(x_{1}\right)}{d x_{1}}=0 .
$$

Therefore, unless $d \xi / d p_{2}=0$ (so that future policies are independent of future politics) or $d \pi / d x_{1}=0$ (so that future politics is independent of today's policies), the second term in this equation will be non-zero, implying that the objective of the welfare maximizing policy maker, and the advice given by economists, should not just be to solve market failures today, but should factor in politics.
} 
and (2) the political dominance of a narrow interest group or segment of society will have deleterious effects (for example, Acemoglu and Robinson, 2012). In this light, it is policies that economically strengthen already dominant groups, or weaken those that are acting as a counterbalance to them, that are especially likely to tilt the balance of political power further and have unintended, counterproductive implications. ${ }^{3}$ In addition, economic reforms that leave the fundamental political and institutional sources of inefficiencies unchanged and instead deal with some of their symptoms in a superficial way also risk a political backlash by violating "political incentive compatibility constraints" - effectively destroying existing political equilibria or coalitions. We show later how this has been an endemic problem with policy reform in Africa where, rather than being targeted at the fundamental political economy problems, reforms often focus on an outcome of these problems, such as poor monetary or fiscal policy.

Of course the devil is in the details. How might current economic policy choices affect future political equilibria? How do political equilibria affect the level of welfare that will be achieved in the future? Clearly, these effects may differ across settings, like democracies vs. nondemocracies, but we will argue that in many instances they seem to be present and of first-order importance.

\section{The Organizational Importance of Economic Rents}

Economic rents create incentives to organize - in particular, to extract and/or take advantage of those rents or to protect them. The existence of organizations has potentially powerful political consequences. thus Thus, eradicating market failures and removing the

\footnotetext{
${ }^{3}$ Following up on footnote 2, one first needs to order policies, for example, such that higher $x$ favors the already politically powerful groups. With this ordering, denote the status quo policies which will apply without any intervention by $x_{1}^{0}$ and $x_{2}^{0}$. Suppose that $x_{2}^{0}>x_{2}^{S W}$, so that the status quo in the future is already biased in favor of the politically powerful, and that $p_{2}$ increases (shifts in favor of the dominant groups) when $x_{1}$ increases. Then any policy reform that involves $x_{1}>x_{1}^{0}$ (so that it favors the politically powerful relative to the status quo today) will tend to increase $p_{2}$ and shift the political equilibrium in the second period further to the benefit of the politically powerful. This tends to lead to yet higher values of $x_{2}$ (thus increasing the gap between actual and socially optimal policies in the second period). Our framework suggests that the political consequences of these types of policies should be carefully studied.
} 
resulting rents will often change investments in organizations by certain individuals and groups, and via this channel influence the political equilibrium. This intuition suggests that economic policy-making should take into account - or at least study - the impact of policy on the political organization of various groups.

\section{Rents, Unionization and Democracy}

In most situations, unions clearly create economic distortions by pushing the wages of their members up relative to non-unionized employees. Unions may also create other distortions, like discouraging employers from adopting certain technologies and efficiencyenhancing practices. As a result, reducing the power of unions to push up wages is often mainstream economic advice. The counterarguments rooted in economic theory typically refer either to the role of unions in securing a more equal distribution of income, especially by improving the pay of lower-wage workers, or to arguments that firms have some monopsony power in setting wages and unions can counterbalance that power.

In the context of our framework, the key point is that any policy choice that reduces the ability of unions to push for high wages - even if it does not involve directly making it harder to organize unions - will indirectly reduce union activity. After all, many workers may no longer find joining unions worthwhile when the premium they receive is limited. In the context of our framework, today's policies affect tomorrow's organizational investments and thus the distribution of political power - in this case the power of unions. Moreover, in many settings, despite the power of unions in the status quo, the balance of power is already tilted in favor of large employers so that weakening unions might create a more tilted balance of political power in society, with the potential dynamic costs that this will engender.

This is because, as we have already noted, unions do not just fight for higher wages or attempt to influence the internal organization of firms; they have also been very active politically in ways that seem likely to affect the political equilibrium. One of the most important consequences of the political power of unions is the role they have played in creating and supporting democratic institutions around the world, particularly starting from a situation in which political power was very unequally distributed in a non-democratic context. A recent literature on the factors influencing the creation of democracy has moved away from earlier work, such as that of Moore (1966) which emphasized the role of the middle class or "the bourgeoisie," and has instead pointed out that it is often the 
working classes or poor segments of society that have played a defining role in the emergence and flourishing of democracy (Rueschemeyer, Stephens and Stephens 1992; Collier and Mahoney 1997; Acemoglu and Robinson 2000, 2006). This literature argues that the extent to which the working class is organized or able to engage in collective action is critical for its ability to push for institutional change. Since unions are in the business of organizing working people, it makes sense that the presence of unions should facilitate collective action that pushes for regime change. A great deal of case study and econometric research supports this emphasis on social conflict (for example, Aidt and Jensen, 2012).

The examples where unions have played a pivotal role in democratization range from the 'first wave of democratization' in Europe prior to World War I (Eley, 2002) through the battle of Solidarity against the communist regime in Poland, to the fight against the Apartheid regime in South Africa by the Congress of South African Trade Unions (COSATU). One of the clearest recent cases is the formation of the Workers Party (PT) in Brazil in 1979. This party emerged in the context of a strike at the Scânia truck factory in São Bernardo. The leader of the São Bernardo metalworkers was a 33 year-old activist called Luis Inácio Lula da Silva, also known as Lula, who helped to organize what was the first in a series of strikes which swept across Brazil, challenging the military dictatorship. On the face of it these strikes were about wages and working conditions, but as Lula later recalled: "I think we can't separate economic and political factors ... The ... struggle was over wages, but in struggling for wages, the working class won a political victory" (quoted in Keck, 1992, p. 65). Formed the year after the strike, the PT was in the vanguard of the successful movement to force the military from power in Brazil.

In summary, policies reducing the effectiveness of unions in negotiating over wages and working conditions for their members will reduce their political power. Though Lula and COSATU managed to organize in hostile political environments, the evidence suggests that unionization rates are sensitive to government policies which facilitate the creation of monopoly power and rents (see Rothstein, 1992, Western, 1999, Schmitt and Mitukiewicz, 2012). If the political power of unions is important in supporting a range of other economic and political outcomes, then correcting the labor market failures associated with unioninduced high wages may backfire.

This perspective can also be applied to U.S. experience with unions. The share of U.S. workers belonging to a union peaked back in the early 1950s. There was an element of policy choice here: after encouraging the growth of unions with the passage of the National 
Labor Relations Act (the "Wagner Act") in 1935 and by various actions during World War II, the bargaining environment became less favorable for unions with the passage of the Labor Management Relations Act of 1947 (the Taft-Hartley Act). Moreover, starting in the 1970s, policies that encouraged free trade increased the level of competition in the U.S. economy, undercutting the ability of a number of private-sector unions to raise wages. Of further significance was the anti-union stance of the Reagan administration (see Farber and Western, 2002, for the legacy of this). The decline in union membership may have had various political economy consequences, for example, as an important contributing factor to the rise in income inequality (Western and Rosenfeld, 2011). More speculatively, it may have also contributed to the explosion in compensation of chief executive officers (DiNardo, Hallock and Pischke, 1997, 2000) and to the rapid deregulation of the financial sector.

\section{Consequences of the Organization of Resource Wealth}

A popular argument claims that the specific form of a country's natural resources have a first-order impact on economics and politics. Botswana's deep-mined diamonds, according to this argument, have different consequences for political stability than Sierra Leone's alluvial diamonds (Ross, 2006). However, the consequences of minerals can depend not so much on their intrinsic characteristics or on whether their extraction is organized efficiently from an economic point of view, but on the political consequences of how their exploitation is structured. We illustrate this with the comparison of the exploitation of the alluvial gold deposits of Australia and the diamond deposits of Sierra Leone. In both cases, for basic economic reasons, free entry into mining was inefficient. Natural resource extraction is a clear case of "congestion": the more others extract, the less will be left for each. One way to address this market failure is to assign exclusive property rights to the natural resources to a large producer, who would plan long-term and eliminate the dissipation of rents that is likely to arise through excessive entry. Another way to organize mining is to allow large numbers of individuals or small firms to search for the resources, possibly subject to registration or other fees.

That the political consequences of the economic organization of mineral extraction may be more important than their direct economic consequences is illustrated by the contrast of the Australian and Sierra Leonean histories. The Australian case suggests that when a large number of independent, small-scale miners are doing the extraction 
and realize their rents may be dissipated, this encourages their political organization as a group, ultimately creating a more balanced political landscape and contributing to the development of democratic politics.the risk of dissipation of the rents of a large number of independent, small-scale miners may contribute to their political organization as a group, ultimately creating a more balanced political landscape and contributing to the development of democratic politics. On the other side, Sierra Leone's experience showcases how the prevalence of large and very profitable mining interests, as well as the political infighting to control and benefit from these mining interests, often has negative and non-democratic implications for the distribution of political power.

In Australia, gold was discovered in New South Wales and then in the newly formed state of Victoria in 1851. The immediate reaction of Australian political elites was to try to ban gold mining in the fear that the labor force on farms and ranches would vanish. If gold mining was to be allowed, it would be only after proper surveys had been made and the land leased out to large enterprises (Hirst, 2008, p. 375). But the gold was on Crown land, and as such outside the direct control of the elites in the Legislative Assembly of New South Wales, who could neither get mining banned nor allocated in large lots. The concerns of the British colonial state about the growing power of local Australian economic and political elites led to the decision to allow anyone to take out a mining license as long as they paid 30 shillings per month. Though this fee was high, it did not stop a massive gold rush. Soon 50 percent of the men in Victoria were working in the gold fields. Of Melbourne's 40 police constables, 38 resigned to go and dig gold. Ships were unable to sail from Melbourne's harbor because their crews deserted (Blainey 2006, p. 40).

As Australia's mining camps spread, resentment grew about the license, which had to be paid whether or not the miner found gold, and further restrictions were placed on the size of claims miners could stake. Punishments were also increased for those found without a license. The miners began to organize to protect their interests and increase their rents by reducing mining licenses. In 1854, they founded the Ballarat Reform League in the town of that name in the middle of the goldfields. In November 1854, the diggers in Ballarat delivered a set of "Resolutions" to the governor which were heavily inspired by the agenda of the "Chartists," a movement of working-class people seeking greater political participation in Britain. (Indeed, the secretary of the Ballarat Reform League, John Humffray, had been a "Chartist" in Wales before emigrating to Australia.) The demands included manhood suffrage, no property requirements to become a member of 
the Victorian Legislative Council and payment of its members (Hirst, 2002, p. 48). They also demanded an end to licenses and the disbanding of the commissioners who collected the license fees on the goldfields. A group of miners, "diggers" as they were known, led by Peter Lalor, decided to refuse to pay for their licenses, took up arms, and built a stockade at Eureka. On December 3, 1854 armed police stormed it. Thirty diggers and five policemen died.

In the outrage that followed, a Royal Commission recommended reform of the license system, also fixing a fee of one pound for a yearly license. Under the 1853 Victoria Constitution, someone in possession of an annual mining license was deemed to have sufficient wealth to be eligible to vote. Thus, at one fell swoop, any digger willing to pay one pound - and many were - was enfranchised. At the same time, to further placate the diggers, the Legislative Council was expanded to allow for representation from the goldfields. In 1855 Humffray and Lalor were elected to the Victoria Legislative Council along with six other diggers. In March 1856, the Legislative Council introduced the world's first effective secret ballot, henceforth known as the "Australian Ballot." All eight diggers voted in favor, and the measure passed by 33 votes to 25 (Hirst, 2006).

The contrast between the Australian experience, where the organization of gold deposits created a large pro-democratic force, and that in Sierra Leone is striking. Prospecting for diamonds began in Sierra Leone in the 1920s, with the first discoveries being made in 1931. Small scale mining started in 1933 in the east of the country, and in 1935 the colonial government gave the Sierra Leone Selection Trust (SLST) practically exclusive prospecting and mining rights for the entire country. To protect these rights from illegal Mining, SLST had its own security force. In his study, van der Lann (1965, p. 79) poses the question: "What is better for the Sierra Leone economy: to have the diamond deposits slowly and steadily exploited by a mining company, or rapidly worked by diggers?" He argues that the SLST was (economically) better both "because the recovery rate of the diggers ... falls far short of the rate of close to 100\% achieved by SLST" (p. 80), and also because the SLST monopoly generated more revenues for the government.

Yet the really important feature of the organization of the diamond mining in Sierra Leone was not the economic costs and benefits of the SLST, but its political consequences. Though SLST struggled to control illegal mining by diggers, the organization of the mining did not create the type of democratic impulse as it had in Australia. One consequence of this was that the independence movement of the 1950s was spearheaded by paramount chiefs and other elites favored by British colonialism. In 1952, when these elite Sierra 
Leoneans began to control the Legislative Council, they chose not to open up diamond mining to Sierra Leoneans, but rather to extract greater taxes from the SLST. In exchange, they helped to enforce the monopoly rights by aggressively punishing illegal mining. The Minister of Mines in charge of this was the future kleptocratic prime minister and president of Sierra Leone, Siaka Stevens. In 1956, the number of illegal diggers had become so large - possibly 75,000 (van der Laan 1965, p. 65) - that security forces were overwhelmed. SLST's monopoly was now restricted to two areas, but these were still the prime deposits of Kono and Tongo Fields. Elsewhere, mining licenses were issued but not to 'strangers'meaning anyone who was not an indigenous resident of the chieftaincy where the mining was to take place.

Naturally, as discussed in Acemoglu and Robinson (2012), there were other historical and institutional factors stacking the cards against the development of the type of inclusive economic and political institutions and policies that would have stimulated economic growth in Sierra Leone. But the arrangements that had been made for accessing natural resources were a key contributor to the fact that during the critical period of the founding of the first political parties in Sierra Leone, they were formed by elites, particularly by the Paramount Chiefs and those connected to them, without the input of the broad mass of Sierra Leoneans (Cartwright, 1970, for an overview). The scene was set for the creation of one-party and authoritarian rule after independence in 1961.

\section{Political Consequences of Inequality}

Removing a market failure will also generally alter the distribution of income in society. For example, when unions are less able to exercise monopoly power, not only will their organization dwindle, but (at least in the absence of robust competition) profits will rise. Income will be typically redistributed from workers to the managers and owners of firms. This shift will also influence the political equilibrium, however.

An example of how an altered distribution of income can have a first-order impact on future politics is provided by the effect of Atlantic trade opportunities on the English political system in the seventeenth century. Because Atlantic trading activities were not the monopoly of the Crown in England at this time, this trade was dominated by independent merchants, adventurers and privateers. Profits from Atlantic trade enriched many of these men, who opposed the Stuart monarchs's absolutism and sought to limit the Crown's prerogatives. As they became richer, they also became more powerful and bolder, 
and were even able to field armies to defeat the monarchy in the English Civil War of the 1640s and then during the Glorious Revolution of 1688. Acemoglu, Johnson and Robinson (2005) and Jha (2010) provide historical and empirical evidence linking the rise of inclusive institutions in England and the Dutch Republic to the rise of merchants and industrialists benefiting from Atlantic trade. Tellingly, this trajectory is very different than the one observed in Portugal or Spain, where Atlantic trading activities were monopolized and allocated by the Crown. In these countries, the riches of trade flowed into the coffers of the already dominant monarchs, strengthening the monarchy, weakening their parliaments, and contributing to the tilted balance of political power, which persisted and underpinned the lack of economic and political development in these parts of Western Europe.

\section{Money and Politics in the United States}

The experience of financial deregulation over the past 30 years in the United States, as analyzed by Johnson and Kwak (2010), provides an illustration of how economic policy designed with a disregard for political implications can be injurious to social welfare. The system of financial and banking regulation which emerged from the Great Depression had many features that were irrational from a purely economic viewpoint. These included the prohibition of interstate banking and the separation of commercial from investment banking. Jayaratne and Strathan (1996), among others, found that the removal of some

of these banking restrictions spurred rapid economic growth. Such reforms are akin to those directly addressing market failures in the sense that they were removing distortions partly introduced by previous policies. But, in common with the other economic policies with potentially counterproductive political consequences, these reforms also tended to strengthen an already powerful constituency, the financial sector.

Financial degulation started small, for example, ending fixed commissions on stock trading in 1975. Then in 1980 Regulation Q, which limited interest rates on savings accounts, was abolished. As Johnson and Kwak (2010) argue, while the banking and financial services industry was not powerful enough at this time to get all the deregulation it wanted, it was strong enough to block new regulation. This was relevant because considerable financial innovation was starting to take place: as one example, Salomon Brothers originated interest rate swaps in 1981. As these new financial instruments developed, and as regulations that limited what financial services banks could perform were incrementally relaxed during this time by regulators and courts, the financial sector became bigger and 
more profitable. Between 1980 and 2005, financial sector profits grew 800 percent in real terms, while nonfinancial profits rose by 250 percent (Johnson and Kwak, 2010, Chapter 3). Between 1998 and 2007, financial sector profits were on average about 30 percent of total profits in the private sector. During this period, the financial sector went from 3.5 percent to almost 6 percent of GDP.

As the banks got bigger and more profitable, they also became more assertive and influential. They started to lobby more and contribute more to political campaigns. While in 1990 the financial sector donated $\$ 61$ million dollars to political campaigns, by 2006 this was $\$ 260$ million (the industry which was the next largest donor, health care, gave only $\$ 100$ million in 2006). Of course, rising wealth and campaign contributions were not the only source of rising political power for the financial industry. There was a revolving door between Wall Street and executive appointments in Washington as well. As Johnson and Kwaak (2010) point out, there was also an intellectual revolution in academic finance involving the pricing of derivative financial instruments and a body of studies arguing for deregulation, all of which was interpreted as bolstering the financial sector's position.

So financial deregulation continued. In 1994, the Riegle-Neal Interstate Banking and Branching Efficiency Act relaxed constraints on inter-state banking and led to a series of mergers which constructed large nationwide banks. JPMorgan Chase and Citicorp were formed, and the Bank of America transformed. In 1999, the Gramm-Leach-Bliley Act effectively codified the demolition of most of the barriers between commercial and investment banking, barriers that had already been falling incrementally for several decades as a result of regulatory and court decisions. But perhaps more important than these changes was the avoidance of regulations: for example, regulations that might have altered how accountants and regulators treated the collateralized debt obligations based on mortgage-backed securities and the credit default swaps sold by insurance companies like the American Insurance Group (AIG). The political power of the financial industry also accentuated the "moral hazard problem" in finance - that large financial institutions can take risks expecting to be bailed out by the government when things get bad. Ultimately, these regulatory changes and the regulatory void, in conjunction with the moral hazard problem, created an environment which encouraged excessive risk-taking and contributed to the 2007-2008 financial crisis.

In terms of our framework, this account illustrates how potentially efficiency-enhancing deregulation may have increased the size and political power of the financial industry, 
which then altered the structure of future regulations and allocations in favor of the financial industry, with potentially adverse consequences for the rest of society. Put differently, the analysis of these economic policies which focused only on their economic costs and benefits but did not take into account the political consequences of the changes they unleashed, dramatically understated the likelihood of the costs that actually occurred.

\section{Russian Privatization}

Most economists favor privatization of industry, and few argue that government ownership of industry is efficient from a cost and benefit perspective. Like deregulation, privatization is also proposed as a way of improving economic efficiency by reversing existing (government-imposed) distortions. Yet the privatization of firms in Russia during the 1990s is another example of a policy with a major effect on income distribution, creating a group of very wealthy individuals and putting in motion significant political changesnot only in terms of the direct negative consequences of the policy, but also in terms of the potential weakening of the reform process and the backlash that these policies created, paving the way for the rise of Vladimir Putin's authoritarian regime.

In the summer of 1991, Boris Yeltsin won the election for the newly created Russian presidency. His platform, on the basis of which he beat four Communists and a hardcore nationalist, included a radical program of market-oriented reform. To implement it, he picked Yegor Gaidar, who in turn asked Anatoly Chubais to be in charge of privatization. Of all the policies that Yeltsin wanted to implement, the privatization of the country's thousands of state-owned firms was perhaps the most critical; but he had no specific plan about how to accomplish it. Gaidar and Chubais came up with a strategy to put the main assets of the Soviet Union into private hands.

Starting in the spring of 1992, small firms like stores and restaurants began to be sold off. People could take ownership of their own apartment for free or almost for free. In late 1992, Chubais turned to the big firms. Yeltsin's team tried to get the public involved in this initial distribution of assets. Large and medium sized enterprises were required to sell 29 percent of their shares in voucher auctions, and in October 1992, each Russian adult was issued vouchers with a nominal value of 10,000 rubles; one's vouchers could be acquired at a local bank for a fee of just 25 rubles. By January 1993, 97 percent of Russians had claimed their vouchers. These vouchers could be sold or used to bid for the shares of specific companies when they privatized. The first voucher auctions were held in 
December 1992, and in total, about 14,000 enterprises held such auctions. However, most assets of these firms went to their workers and managers. The law allowed for workers and managers to buy 51 percent of the voting shares of a firm at a discount and using the firms' own funds. In effect, the majority of privatizing firms' assets were handed to insiders at huge discounts.

The most controversial stage of the privatization - and in hindsight the most consequential - was the loans-for-shares deal in 1995. State shares in twelve highly profitable enterprises concentrated in the energy sector were used as collateral for bank loans. If the loans were not paid off, and the government never had any intention of paying them off, the banks would have the right to sell the shares. Between November 1996 and February 1997, sales happened for the shares of several large firms including Yukos, Sidanko and Surgutneftegaz, and in each case, the shares were bought by the banks themselves in auctions where outside bids were ignored or disqualified. Freeland (2000) and Hoffman (2002) provide overviews of these events and a description of the resulting rise of the oligarchs. Not only did this type of privatization massively enrich and empower the oligarchs, but it also failed to create a large number of small shareholders. In 1994, workers owned 50 percent of the average Russian enterprise; by 1999, this figure had dropped to 36 percent. By 2005, 71 percent of medium and large industry and communications enterprises had a single shareholder who owned half the stock (Treisman, 2011, pp. 223-224).

The driving force behind privatization was textbook economics, to move Russia from central planning and state ownership to a much more efficient market economy. This was certainly the view of many economists at the time, and the main debate was about how fast to privatize (Aghion and Blanchard, 1994), not whether to maintan state ownership or not (for example, arguments that privatization might create a private monopoly, with even worse economic consequences than public ownership, as suggested by Borenstein, 2002, in the context of California, were not commonly raised, though since then some, including Black, Kraakman, and Tarassova, 2000, Stiglitz, 2002, and Goldman, 2003, have argued against privatization on purely economic grounds). To the extent that economists worried about the political economy of the process, they did not consider that privatization might have adverse political consequences. Rather, they focused on how to structure the transition so that the political coalition in favor of privatization would stay on track (Dewatripont and Roland, 1992), or on the ex ante political constraints shaping the form of privatization (Shleifer and Treisman, 2000). In fact, a common view was that the particular details of Russia's privatization were not of first-order importance, essentially 
because of the "good economics is good politics" argument. Boycko, Shleifer and Vishny (1995, pp. 10-11), for example, asserted: "[A]t least in Russia, political influence over economic life was the fundamental cause of economic inefficiency, and the principal objective of economic reform was, therefore, to depoliticize economic life ... Privatization fosters depoliticization because it robs politicians of control over firms."

There is indeed evidence that Russia's privatization was initially good for the economy, and even the oligarchs appear to have at first invested heavily in their new firms (Treisman 2011, Åslund, 2007 Chapter 6). For example, Shleifer and Treisman (2004, p. 29) ask: "Have the oligarchs stripped assets from the companies they acquired in privatization, rather than investing in them? The audited financial statements of these companies suggest that their assets have grown dramatically, especially since 1998 ... And the major oligarchs have been investing hundreds of millions of dollars annually in their companies ..."

But our emphasis here is on the political consequences of the privatization. The privatization enriched and also temporarily politically empowered a group of unscrupulous oligarchs; in fact, so much so that there was a significant increase in Russian inequality following privatization (Alexeev 1999). Even more importantly, the economic and political inequality it created induced a backlash against the process of economic and political reform in Russia, ultimately re-creating authoritarianism and firmly entrenching a form of state-led crony capitalism (see Guriev and Sonin, 2008, for a theoretical analysis). There are several layers to understanding how this political equilibrium evolved. First, privatization failed to create the type of broad distribution of assets which would have provided the economic underpinning for the nascent democracy. Second, the distribution of gains was not just narrow, it was illegitimate because the large increase in inequality favored the politically enterprising and the connected. Third, the concentrated nature of the assets which emerged from this process and the huge rents that were up for grabs made it very easy for the KGB, re-energized under the leadership of Putin, to wrestle back control of the economy. Finally, the way in which the privatization took place may have undermined the incentives of the oligarchs to push for better institutions (Sonin 2003), and may also have fueled popular support for Putin's political strategy.

Our bottom line on the experience of Russian privatization is that a purely economic approach to moving from collectively to privately owned assets turned out to be woefully inadequate - as was a political economy approach based on the assertion that "good economics is good politics". The evidence instead suggests that privatization, particularly 
its form, had a defining impact on Russian politics and contributed to the rise of an authoritarian and repressive regime ruling over a much more unequal society.

\section{Violating Political Incentive Constraints}

Politicians are often constrained by "political incentive compatibility constraints". These determine the expected utility that a political leader in power must obtain himself or give to organized interests if he or she wishes to stay in power. Yet removing market failures, without recognizing and addressing the fundamental political and institutional sources of distortions, may violate these constraints. Put differently, a set of policies which may seem

deeply misguided by the standards of basic textbook economics may nonetheless be serving the political economy purpose of holding together a governing coalition. By implication, removing such market failures can weaken existing coalitions or disrupt equilibria. The result may be the rise of new coalitions or new types of equilibria, which might reinstate the market failures or create new ones, because they are useful in binding together the governing coalition or creating rents for the rulers. This type of re-creation of distortions was dubbed "the seesaw effect" in Acemoglu, Johnson, Querubín and Robinson's (2008) study of central bank independence under weak institutions. But more ominously, the results of violating political incentive compatibility constraints might also be a period of civil unrest, with high costs of its own, or even civil war. Thus, addressing market failures in this setting without appropriate consideration of political consequences may be ineffective or even counterproductive in broad social welfare terms.

\section{Policy Reform, Instability and Violence}

The experience of Ghana's Prime Minister in 1971, Kofi Busia, illustrates that policy advice should take into account that politicians face political constraints, and that in this case as well, good economics is not necessarily good politics.

Busia had come to power in 1969 after the military junta, which had ejected the increasingly autocratic government of Kwame Nkrumah in 1966, had finally given up power. Busia immediately faced a deep economic crisis, underpinned by unsustainable expansionary economic policies, distortionary price controls implemented through marketing boards, and an overvalued exchange rate. But these policies were not adopted because Ghanaian leaders, Busia included, believed that they were good economics. Nor 
were they embraced as a way to develop the country. They were chosen to satisfy political constraints. The expansionary economic policies and overvalued exchange rates enabled Busia and his predecessors to transfer resources to urban groups. Price controls also had a strong political logic first recognized by Bates's classic (1981) book: market distortions and price controls create valuable rents which can then be allocated to generate political support. Ghanaian pricing policies squeezed agriculture, delivering cheap food to the politically more powerful urban constituencies, and generated revenues which financed government spending — and lined politicians' pockets.

But these policies did mean that balance of payments crises and foreign exchange shortages, as well as economic recession, became unavoidable. To outside institutions such as the World Bank and the International Monetary Fund (IMF), the problem and its solution were clear: distortionary policies had to be removed. Faced with economic crisis and international pressure, Busia caved in and signed an agreement with the IMF on December 27, 1971, which included a massive 44 percent devaluation of the currency.

Whatever the textbook economic logic behind the reforms, the political outcome was dire. The devaluation was followed by rioting, continuous demonstrations and discontent. Two weeks after the announcement of the devaluation, Busia was overthrown in a military coup, which immediately reversed the devaluation. State controls over prices, wages, marketing boards and exchange rates were the heart of a Ghanaian politician's patronage network, and any politician who lost the support of this network was susceptible both at the polls and against the military.

The combination of policy reform followed by violence in Ghana is not an isolated instance. As Herbst (1990) and Reno (1995, 1998) have pointed out, there is a general pattern in countries across West Africa of policy reform being followed by violence: indeed, one reason that policy reform is so seldom implemented in Africa (van de Walle, 2001) is because politicians know that it is expected to lead to the breakdown of political order.

Reno's $(1995,1998)$ analysis of Sierra Leone is telling. After the rise to power of former Minister of Mines Siaka Stevens and his All People's Congress Party in 1968, a political compact emerged in Sierra Leone based on the creation and distribution of rents. Patrimonialism and redistribution of these rents was perfected to a fine art by Stevens, who manipulated traditional political institutions such as the chieftaincy and bought support on a massive scale using rents, patronage and jobs.

Stevens ruled until 1985 when he gave way to his hand-picked successor Joseph Momoh, who ruled the country until he was overthrown by a military coup in 1992. Barely any 
public goods were provided in the country in the 40 years prior to the end of the civil war and re-democratization in 2002. The roads fell to pieces and schools disintegrated. National television broadcasts stopped in 1987 when the transmitter was sold by the Minister of Information, and in 1989 a radio tower which relayed radio signals outside Freetown fell down, ending transmissions outside the capital (Reno, 2003, p. 48). The Sierra Leone Produce Marketing Board had a monopsony over all export crops and paid farmers very low prices - as low as 40 percent of the world level (Davies, 2007). The exchange rate was massively overvalued, creating a black market. GDP per capita fell almost monotonically from the early 1970s onwards and reached about 40 percent of the level recorded at independence by the end of the civil war in the early 2000s (Davies, 2007).

But ironically, Reno argues that attempts by the international community to improve the economic policies of Sierra Leone had the unintended consequence of intensifying the existing violence and arguably even pushing the country into a bloody civil war. Sierra Leone first called in the IMF in 1979, and after that entered into a long series of negotiations. As its economy declined in the 1980s, the government's need for international resources escalated, but the problem from the point of view of President Momoh was that "fiscal responsibility and budget cutting in this context only hastened the urgency of finding alternative means of ensuring associates' loyalty" (Reno 1995, p. 156). More importantly, "Momoh was losing resources to enforce political control. As revenue shortfalls and IMF austerity measures shut down parts of the state bureaucracy that had survived ... Momoh's allies sought other means of supporting themselves as they lost access to benefits ... The president could no longer control disobedience ... The reform of 'bad policies' neither restored the president's political control, nor tapped 'entrepreneurial energies' which were now directed at evading the president's authority." (Reno, 1995, p. 161).

In short, well-intentioned economic policies imposed on the regime by economists trying to redress market failures and policy disrortions robbed President Momoh of the instruments he had used to buy political support. As a result, he switched to a different political strategy, substituting direct force and coercion for buying people off. In January 1990, Momoh launched 'Operation Clean Slate' which was in effect an attempt to use the army to take over the diamond mining areas. Without the usual instruments of patronage, such as public sector employment and contracting, Momoh turned to coercion to try to grab what rents remained in the country. The resentment this caused in the east 
helped to fuel a bloody ten-year civil war (Richards, 1996). Though Momoh's regime was clearly extractive, kleptocratic and repressive, the subsequent civil war was certainly not the intended objective or a desirable outcome, and Reno's analysis highlights how unintended political consequences are commonplace when reform is imposed from the outside without understanding the political equilibrium and the political incentive compatibility constraints on the ground.

\section{Rents and the Natural State}

The recent book by North, Wallis and Weingast (2010) also indirectly underscores that the "good economics is good politics" dictum is fallacious by providing several counterexamples in the context of what they call the "natural state." In their conceptual framework for explaining economic development, they argue that there is a basic dichotomy between two types of social orders: "open access" characterized by economic development, democracy, rich and vibrant civil society with lots of organizations and widespread impersonal social relationships, including the rule of law, and secure property rights; and "limited access" characterized by poor economic growth, a small number of organizations and social relations along personal lines with privileges, unequal enforcement of laws and insecure property rights. All social orders, they argue, are constructed to control the threat and use of violence, but they do so in different ways with different consequences for economic incentives and development. In particular, a natural state is a limited access order where the key to controlling violence is the creation of rents. Echoing Bates's analysis we discussed above, they write (p. 17):

"[S]ystematic rent creation through limited access in a natural state is not simply a method of lining the pockets of the dominant coalition; it is the essential means of controlling violence. Rent-creation, limits on competition, and access to organizations are central to the nature of the state, its institutions, and the society's performance. Limiting the ability to form contractual organizations only to members of the coalition ties the interests of powerful elites directly to the survival of the coalition, thus ensuring their continued cooperation."

In the world of the natural state-limited access orders, which they claim is a general model for the political economy of poor countries - good economics is almost never good 
politics. As North, Wallis, Webb and Weingast (2012, p. 18) put it: "Because elites know that violence will reduce their own rents, they have incentives not to fight. Furthermore, each elite understands that other elites face similar incentives. In this way, the political system of a natural state manipulates the economic system to produce rents that then secure political order." They summarize their argument by stating (p. 7):

"[T]he appropriate counterfactual from eliminating rents is not a competitive market economy ... but a society in disorder and violence."

\section{Concluding Remarks}

There is a broad - even if not always explicitly articulated - consensus amongst economists that, if possible, public policy should always seek ways of reducing or removing market failures and policy distortions. In this essay, we have argued that this conclusion is often incorrect because it ignores politics. In fact, the extant political equilibrium may crucially depend on the presence of the market failure. Economic reforms implemented without an understanding of their political consequences, rather than promoting economic efficiency, can significantly reduce it.

Our argument is related to but different from the classical second-best caveat of Lancaster and Lipsey (1956) for two reasons. First, it is not the interaction of several market failures but the implications of current policy reforms on future political equilibria that are at the heart of our argument. Second, though much work still remains to be done in clarifying the linkages between economic policies and future political equilibria, our approach does not simply point out that any economic reform might adversely affect future political equilibria. Rather, building on basic political economy insights, it highlights that one should be particularly careful about the political impacts of economic reforms that change the distribution of income or rents in society in a direction benefiting already powerful groups. In such cases, well-intentioned economic policies might tilt the balance of political power even further in favor of dominant groups, creating significant adverse consequences for future political equilibria.

We are of course not the first ones to point out that the political economy of economic policy matters, nor that a standard cost-benefit framework for the analysis of policy is inadequate because it leaves out politics. Since the 1980s, a vibrant literature in political economy has sought to develop positive models of how policy actually gets chosen, which 
involves modelling politics and the decision-making process (for overviews, see Drazen, 2000; Persson and Tabellini, 2000; Besley, 2007; Acemoglu and Robinson, 2006). That being said, existing political economy analyses either do not focus on this question or else emphasize that, if politically possible, market failures should be removed. Dixit (1997) and Drazen (2002) have argued that policy (or institutional) advice must be given in a way that takes seriously the constraint that policy is chosen as part of a political equilibrium - implying that policy advice should be tempered by what is incentive compatible for politicians. Nevertheless, to the best of our knowledge, our main argument in this paper has not been made before. Our argument is that economic policy should not just focus on removing market failures and correcting distortions but, particularly when it will impact the distribution of income and rents in society in a direction that further strengthens already dominant groups, its implications for future political equilibria should be factored in. It thus calls for a different - and explicitly political economy based - framework for the analysis of economic policy. Much of the conceptual, theoretical and empirical foundations of such a framework remain areas for future work.

\section{References}

Acemoglu, Daron, Simon Johnson and James A. Robinson (2005) The Rise of Europe: Atlantic Trade, Institutional Change and Economic Growth, American Economic Review, $95,546-579$.

Acemoglu, Daron, Simon Johnson, Pablo Querubín and James A. Robinson (2008) When Does Policy Reform Work? The Case of Central Bank Independence, Brookings Papers on Economic Activity, Spring 2008, 351-417.

Acemoglu, Daron and James A. Robinson (2000) Why Did the West Extend the Franchise? Growth, Inequality and Democracy in Historical Perspective, Quarterly Journal of Economics, CXV, 1167-1199.

Acemoglu, Daron and James A. Robinson (2006) Economic Origins of Dictatorship and Democracy, New York: Cambridge University Press.

Acemoglu, Daron and James A. Robinson (2012) Why Nations Fail: The Origins of Power, Prosperity, and Poverty, New York: Crown.

Aghion, Philippe and Olivier J. Blanchard (1994) On the Speed of Transition in Central Europe, NBER Macroeconomics Annual, 283-330.

Aidt, Toke S. and Peter S. Jensen (2012) Workers of the World Unite! 
Franchise Extensions and the Threat of Revolution in Europe, 1820-1938, http://www.econ.cam.ac.uk/faculty/aidt/papers/web/workers/workers.pdf

Alexeev, Michael (1999) Privatization and the Distribution of Wealth in Russia, Economics of Transition, 7, 449-465.

Åslund, Anders (2007) How Capitalism was Built: The Transformation of Central and Eastern Europe, Russia and Central Asia, New York: Cambridge University Press.

Banerjee, Abhijit V. (2012) "Poor Economics - Effective Poverty Reduction Policies," Kapuscinsky Development Lecture, http://kapuscinskilectures.eu/lectures/pooreconomics/.

Banerjee, Abhijit V. and Esther Duflo (2011) Poor Economics, New York: Public Affairs Press.

Bates, Robert H. (1981) Markets and States in Tropical Africa, Berkeley: University of California Press.

Besley, Timothy (2007) Principled Agents?: The Political Economy of Good Government, New York: Oxford University Press.

Black, Bernard, Reinier Kraakman, and Anna Tarassova (2000) Russian Privatization and Corporate Governance: What Went Wrong? Stanford Law Review, 52, 1731-1808.

Blainey, Geoffrey (2006) A History of Victoria, New York: Cambridge University Press.

Borenstein, Severin (2002). The Trouble With Electricity Markets: Understanding California's Restructuring Disaster. Journal of Economic Perspectives, 16(1): 191-211.

Boycko, Maxim, Andrei Shleifer and Robert W. Vishny (1995) Privatizing Russia, Cambridge: MIT Press.

Cartwright, John R. (1970) Politics in Sierra Leone 1947-67, Toronto: University of Toronto Press.

Collier, Ruth Berins and James Mahoney (1997) Adding Collective Actors to Collective Outcomes: Labor and Recent Democratization in South America and Southern Europe, Comparative Politics, 29(3), 285-303.

Davies, Victor A.B. (2007) Sierra Leone's economic growth performance, 1861-2000, in Benno J. Ndulu et al eds. The Political Economy of Growth in Africa, 1960-2000, Volume 2, New York: Cambridge University Press.

Dewatripont, Mathias and Gérard Roland (1992) Economic Reform and Dynamic Political Constraints, Review of Economic Studies, 59, 703-30.

DiNardo, John, Kevin Hallock, Jörn-Steffen Pischke (1997) Unions and Managerial 
Pay, NBER Working Paper No. 6318.

DiNardo, John, Kevin Hallock, Jörn-Steffen Pischke (2000) Unions and the Labor Market for Managers, Institute for the Study of Labor (IZA) Discussion Paper No. 150

Dixit, Avinash (1997) Economists as Advisers to Politicians and Society, Economics \& Politics, 9(3), 225-230.

Drazen, Allan M. (2000) Political Economy in Macroeconomics, Princeton: Princeton University Press.

Drazen, Allan M. (2002) Conditionality and Ownership in IMF Lending: A Political Economy Approach, IMF Staff Papers, 49.

Eley, Geoffrey (2002) Forging Democracy: The History of the Left in Europe, 18502000, New York: Oxford University Press.

Farber, Henry S. and Bruce Western (2002) "Ronald Reagan and the Politics of Declining Union Organization." British Journal of Industrial Relations, 40:385-402.

Freeland, Chrystia (2000) Sale of the Century: Russia's Wild Rise from Communism to Capitalism, New York: Crown Business.

Goldman, Marshall I. (2003) The Privatization of Russia: Russian Reform Goes Awry, New York: Routledge.

Guriev, Sergei M. and Konstantin Sonin (2008) Dictators and Oligarchs: A Dynamic Theory of Contested Property Rights, Journal of Public Economics, 93(1-2), 1-13.

Herbst, Jeffrey I. (1990) The Structural Adjustment of Politics in Africa, World Development, 18(7), 949-958.

Hirst, John B. (2002) Australia's Democracy: A Short History, Sydney: Allen and Unwin.

Hirst, John B. (2006) Making Votes Secret, Melbourne: Victorian Electoral Commission.

Hirst, John B. (2008) Freedom on the Fatal Shore, Melbourne: Black Inc.

Hoffman, David (2002) The Oligarchs, New York: Public Affairs.

Jayaratne, Jith and Philip E. Strathan (1996) The Finance-Growth Nexus: Evidence from Bank Branch Deregulation, Quarterly Journal of Economics, 111(3), 639-670.

Jha, Suamitra (2010) Financial Innovation and Political Development: Evidence from Revolutionary England,

http://papers.ssrn.com/sol3/papers.cfm?abstract_id=934943

Johnson, Simon and James Kwak (2010) 13 Bankers: The Wall Street Takeover and the Next Financial Meltdown, Pantheon: New York. 
Keck, Margaret E. (1992) The Workers' Party and Democratization in Brazil, New Haven: Yale University Press.

Killick, Tony (1978) Development Economics in Action, London: Heinemann.

Van der Laan, H.L. (1965) The Sierra Leone Diamonds; an economic study covering the years 1952-1961, London: Oxford University Press.

Lancaster, Kelvin and Richard G. Lipsey (1956) The General Theory of Second Best, Review of Economic Studies, 24(1), 11-32.

Moore, Barrington (1966) The Social Origins of Dictatorship and Democracy: Lord and Peasant in the Making of the Modern World, Boston: Beacon Press.

Mulligan, Casey B. and Kevin K. Tsui (2006) Political Competitiveness, NBER Working Paper 12653.

Mulligan, Casey B. and Kevin K. Tsui (2008) Political Entry, Public Policies, and the Economy, NBER Working Paper 13830.

North, Douglass C., John J. Wallis and Barry R. Weingast (2010) Violence and Social Orders: A Conceptual Framework for Interpreting Recorded Human History, New York: Cambridge University Press.

North, Douglass C., John J. Wallis, Steven B. Webb and Barry Weingast (2012) Limited Acess Orders: An Introduction to the Conceptual Framework, in Douglass C. North, John J. Wallis, Steven B. Webb and Barry Weingast eds. In the Shadow of Violence: Politics, Economics, and the Problem of Development and Limited Access Societies, New York: Cambridge University Press.

Persson, Torsten and Guido Tabellini (2000) Political Economics, Cambridge: MIT Press.

Pigou, Arthur C. (1912) Wealth and Welfare, London: Macmillan \& Co.

Reno, William (1995) Corruption and State Politics in Sierra Leone, New York: Cambridge Universty Press.

Reno, William (1998) Warlords Politics and African States, Boulder: Lynne Rienner.

Reno, William (2003) Political Networks in a Failing State: The Roots and Future of Violent Conflict in Sierra Leone, IPG, 2, 44-66.

Richards, Paul (1996) Fighting for the Rainforest: War, Youth and Resources in Sierra Leone, Oxford: James Currey.

Rodrik, Dani (2007) One Economics, Many Recipes: Globalization, Institutions, and Economic Growth, Princeton: Princeton University Press.

Ross, Michael L. (2006) A Closer Look at Oil, Diamonds and Civil War, Annual 
Review of Political Science, 9, 265-300.

Rothstein, Bo (1992) Labor-Market Institutions and Working-Class Strength, in Sven Steinmo, Kathleen Thelen and Frank Longstreth eds. Structuring Politics: Historical Institutionalism in Comparative Analysis, New York: Cambridge University Press.

Rueschemeyer, Dietrich, Evelyn H. Stephens and John D. Stephens (1992) Capitalist Development and Democracy, New York: Cambridge University Press.

Sachs, Jeffrey D. (2005) End of Poverty: Economic Possibilities for Our Time, New York: Penguin Press.

Sachs, Jeffrey D. et al. (2004) Ending Africa's Poverty Trap Brookings Papers on Economic Activity, 2004(1): 117-240.

Samuelson, Paul A. (1947) Foundations of Economic Analysis, Cambridge: Harvard University Press.

Schmitt, John and Alexandra Mitukiewicz (2012) Politics matter: changes in unionisation rates in rich countries, 1960-2010, Industrial Relations Journal, 43(3), 260-280.

Shleifer, Andrei and Daniel Treisman (2000) Without a Map: Political Tactics and Economic Reform in Russia, Cambridge: MIT Press.

Shleifer, Andrei and Daniel Treisman (2004) A Normal Country, Foreign Affairs, 83(2), 20-38.

Sonin, Konstantin (2003) Why the Rich May Favor Poor Protection of Property Rights, Journal of Comparative Economics, 31(4), 715-731.

Stiglitz, Joseph E. (2002) Globalization and its Discontents, New York: Norton \& Co. Townsend, Robert M. (2011) Financial Systems in Developing Economies: Growth, Inequality and Policy Evaluation in Thailand, New York: Oxford University Press.

Treisman, Daniel (2011) The Return: Russia's Journey from Gorbachev to Medvedev, New York: The Free Press.

van de Walle, Nicolas (2001) African Economies and the Politics of Permanent Crisis, 1979-1999, New York: Cambridge University Press.

Western, Bruce (1999) Between Class and Market: Postwar Unionization in the Capitalist Democracies, Princeton: Princeton University Press.

Western, Bruce and Jake Rosenfeld. (2011) "Unions, Norms, and the Rise in US Wage Inequality." American Sociological Review 76:513-537.

Wittman, Donald (1989) Why Democracies are Efficient, Journal of Political Economy, 97(6), 1395-1424.

Wittman, Donald (1995) The Myth of Democratic Failure: Why Political Institutions 
are Efficient, Chicago: University of Chicago Press. 